\title{
Psychometric Evidence of the Diener's Satisfaction with Life Scale in Peruvian Elderly
}

Evidencia Psicométrica de la Escala de Satisfacción con la Vida de Diener en adultos mayores peruanos

Evidência psicométrica da Escala de Satisfação com a Vida de Diener em Pessoas Idosas Peruanas

Tomás Caycho-Rodríguez, MSc ${ }^{1 *}$;

José Ventura-León, MSc';

Cirilo H. García Cadena, PhD²;

Miguel Barboza-Palomino, MSc';

Walter L. Arias Gallegos, MSc

Julio Dominguez-Vergara, MSc';

Karla Azabache-Alvarado, MSc';

Isabel Cabrera-Orosco, MSc4;

Antonio Samaniego Pinho, MSc ${ }^{5}$

Received: November 20th, 2017 / Accepted: May 15th, 2018 Dor: http://dx.doi.org/10.12804/revistas.urosario.edu.co/revsalud/a.7267

To cite this article: Caycho-Rodríguez T, Ventura-León J, García-Cadena CH, Barboza-Palomino M, Arias-Gallegos WL, Dominguez-Vergara J, et al. Psychometric Evidence of the Diener's Satisfaction with Life Scale in Peruvian Elderly. Rev Cienc Salud. 2018;16(3):473-91. Dor: http://dx.doi.org/10.12804/revistas.urosario.edu.co/revsalud/a.7267

1 Universidad Privada del Norte, Lima, Perú.

Corresponding author: tomas.caycho@upn.pe

2 Universidad Autónoma de Nuevo León, México.

3 Universidad Católica San Pablo, Arequipa, Perú.

4 Universidad Continental, Lima, Perú.

5 Universidad Nacional de Asunción, Paraguay. 
Introduction: In recent years, satisfaction with life has aroused the interest of gerontological research, thus being one of the most used concepts to measure subjective well-being, in addition to being an indicator of successful aging. Materials and methods: The psychometric properties of the Diener's Satisfaction with Life Scale were assessed in Peruvian elderly individuals. The instrument was applied to 236 elderly from the city of Trujillo ( $78.4 \%$ female and $21.6 \%$ male), with an average age of 72.8 years old, and their standard deviation $=6.90$. In order to obtain convergent and discriminant validity, the tests Single Item of Satisfaction with Life Scale, Brief Resilient Coping Scale and the Geriatric Depression Scale were conducted. Results: Diener's Satisfaction with Life Scale shows a one-dimensional structure $\left(\chi 2=10.960, d f=5, p=.05, \chi 2 / d f=2.192, G_{F I}=.983, C_{F I}=.994,{ }_{N F I}=.988 ;{ }_{R M S E A}=.071\right.$ [CI $90 \% .000, .129$ ]; and $S R M R=.013$ ), presenting positive correlations with resilience and negative correlations with depression. Moreover, it presents a high reliability index estimated by the method of internal consistency with the Cronbach's Alpha Test ( $\alpha=.93)$, Omega coefficient $(\omega=.93$; cr $95 \%: .92-.95)$ and GLB $=.94$. Conclusion: For purposes of research - among other-, we recommend the use of the Diener's Satisfaction with Life Scale for Peruvian elderly persons.

Keywords: Satisfaction with life, elderly, validity, reliability.

\section{Resumen}

Introducción: en los últimos años, la satisfacción con la vida ha despertado el interés de la investigación gerontológica, siendo uno de los conceptos más utilizados para medir el bienestar subjetivo, además de constituir un indicador del envejecimiento exitoso. Materiales y métodos: se evaluaron las propiedades psicométricas de la Escala de Satisfacción con la Vida de Diener en adultos mayores peruanos. Participaron 236 personas ( $78.40 \%$ mujeres; $21.60 \%$ hombres). La edad promedio fue de 72.8 años y su desviación estándar = 6.90 (desviación standard). Para obtener evidencia de validez convergente y discriminante se aplicaron la prueba de Ítem Único de Satisfacción con la Vida, la Brief Resilient Coping Scale y la Escala de Depresión Geriátrica. Resultados: se encuentra que la Escala de Satisfacción con la Vida muestra una estructura unidimensional $(\chi 2=10.960, \mathrm{df}=5, \mathrm{p}=.05, \chi 2 / \mathrm{df}=2.192$, GFI $=.983$, CFI $=.994$, $\mathrm{NFI}=.988 ;$ RMSEA $=.071$ [IC $90 \% .000, .129$ ]; $\mathrm{y}$ SRMR $=.013$ ), se relaciona positivamente con la resiliencia y negativamente con la depresión. Además, presenta altos índices de consistencia interna (alfa = .93; Ic $95 \%: .90-.94$; omega = .93; ic $95 \%: .92-.95$ y GLB =.94). Conclusión: cuando menos, para propósitos de investigación se recomienda uso de la Escala de Satisfacción con la Vida en adultos mayores peruanos.

Palabras clave: satisfacción con la vida, adulto mayor, validez, confiabilidad.

\section{Resumo}

Introdução: nos últimos anos, a satisfação com a vida tem despertado o interesse da investigação gerontológica, sendo um dos conceitos mais utilizados para medir o bem-estar subjetivo, para além de construir um indicador do envelhecimento bem-sucedido. Materiais e métodos: avaliaram-se as propriedades psicométricas da Escala de Satisfação com a Vida de Diener em idosos peruanos. Participaram 236 pessoas (78.40\% mulheres; 21.60\% homens). A idade média foi de 72.8 anos e Desvio padrão = 6.90. para obter evidência de validez convergente e discriminante, se aplicaram a prova de Item Único de Satisfação com a Vida, o Brief Resilient Coping Scale e a Escala de Depressão Geriátrica. Resultados: encontra-se que a Escala de Satisfação com a Vida mostra uma estrutura unidimensional $(\chi 2=10.960, \mathrm{df}=5, \mathrm{p}=.05, \chi 2 / \mathrm{df}=2.192$, GFI $=.983$, CFI $=.994$, NFI $=.988$; RMSEA $=.071$ [IC90 $2 \% .000, .129$ ]; e SRMR $=.013$ ), se relaciona positivamente com a resiliência e negativamente com a depressão. Para além disso, apresenta altos índices de consistência interna (alfa = .93; ic 95\%:.90-.94; omega=.93; Ic 95\%: .92-.95 e GLB = .94). Conclusão: pelo menos para propósitos de pesquisa, recomenda-se o uso da Escala de Satisfação com a Vida em idosos peruanos.

Palavras-chave: satisfação com a vida, idoso, validez, confiabilidade. 


\section{Introduction}

$\mathrm{I}^{\mathrm{n}}$

$n$ recent years, satisfaction with life (sL) has risen the interest of gerontological research, thus being one of the most used concepts to measure subjective well-being, in addition to being an indicator of successful aging and of quality of life of persons older than 60 years old, due to its relation with physic and psychological health, as well as a predictor of mortality and morbidity (1-7).

Evidence proves that elderly people (ЕР) who are not satisfied with their own lives have a higher probability of risk of depression and of having suicide attempts $(8,9)$. In this sense, it is common to use Ls measurements in general surveys on well-being in different countries (10). For instance, in the United States ss measurements are used as an indicator of the effectiveness of the public health policies in quality of life and well-being by different populations at risk, as it is the case of the EP $(11,12)$.

SL is the cognitive dimension of the subjective well-being that is defined as the assessment of quality of life in general, or of specific domains like job, family, friends, among others (13-15).

Different studies report diverse information on the degree variability and the significance of sL along the life course $(3,16)$. Considering the former, and contrary to expectations, certain researches suggest that su does not necessarily decreases with age (17). Researches with elderly people in Europe and the United States point out that after the age of 50 years old, a significant SL increase takes place, until approximately the age of 70 or 80 years old, a period of time in which it decreases as a result of the rising dependence, health problems, the loss of close relationships and the approaching of death $(1,18-26)$. This phenomenon is called "the paradox of well-being" and has been studied in different contexts (18-20, 27-29). Some studies, on the contrary, have documented a relevant Ls fall with the time passing, while other have reported stable sL levels $(20,30,31)$. Recent studies point out that EP present different paces of change relating their Ls degrees (32). In respect of the meaning of the su, a study analyzing the systemic variation of the concept of well-being in relation to age reported that EP define sL as the ability to keep up with the activities that they have always carried out over their entire lives (33).

Together with age, other factors such as gender, educational level, religion, family environment, socioeconomic status and social support are associated with the changes observed in the SL of the ер $(6,34)$. So, some studies indicate that women present higher su levels than men, other provide evidence that gender is not associated to SL $(35,36)$. Likewise, EP who exhibit low mood present a lower sL, a fact that becomes more chronic if the person lives alone or has no networks of social support and presents serious medical conditions, lacking physical activity and/or isolation (37-40). A study carried out with persons aged between 60 and 89 years old in six European countries showed that unsatisfying social contacts, 
low self-esteem levels, deficient financial resources and the feeling of having many health problems are risk factors for a low sL (41).

Following Fagerström, Lindwall, Berg and Rennemark, the number of associated factors, as well as variations in the su levels and significance along the life cycle provide evidence of the complexity and importance of a scientific study for the purpose of promoting and adequately conducting healthcare in human groups with different ages and needs (16). Against this background, it is important to have the Ls measurement tools as part of the instruments assessing the impact of the health promotion and prevention actions based on the established changes in the sL of the older persons.

Regarding SL assessment in EP, instruments like the Life Satisfaction Index-Well-Being, the Philadelphia Geriatric Center Morale Scale, the Salomon-Conte Life Satisfaction in the Elderly Scale, or even ad hoc designed surveys have been used (42-45). These instruments are characterized by consisting of 8 to 40 items, as well as by assessing different Ls dimensions.

Against this background, instruments providing evidence of validity and reliability of rapid and easy implementation, which produce a good acceptance of the health professionals, and that are tolerated and accepted by the older people, become necessary. Among these, one of the most known instruments is the Diener's Satisfaction with Life Scale (swLs) that has been used in over 4000 studies $(46,47)$. The swls is a brief one-dimensional measure of five items that measures the overall assessment a person makes of his/her own life. It has been carried out in persons of different age groups in various countries $(48,49)$. The swLs is of public domain and in its website (http://internal.psychology.illinois.edu/ ediener/ SWLS.html) information is given on how to apply and interpret it, this information is also available translated into 27 languages.

Currently, different surveys conducted in EP using exploratory and confirmatory analyses point out that the five swLs items constitute a one-dimensional structure with factorial loads varying between .43 and .93 , and adequate reliability estimations with Cronbach's alpha coefficients oscillating between .75 and .92 (48-53). Additionally, the swLs has shown positive correlations with emotional support measures, self-perceived health, perceived control; and negative correlations with depressive symptoms and pain $(48,51)$. Other studies have assessed its cross-cultural measurement invariance (49). These findings provide evidence for considering swLs a valid and reliable measure of the sL in ЕP.

Even though studies analyzing swls validity and reliability in EP have been conducted in Latin America, a review of the scientific literature do not show any study of this kind with Peruvian EP; hence the question: does the swls maintain its adequate psychometric properties with Peruvian ер? $(49,51)$. For this reason, the aim of the present study is to analyze the (construct, convergent, discriminant) validity and reliability evidences of the swLs for its implementation in EP in Peru. Considering the presented arguments, following hypotheses are formulated: ( $a$ ) a swLs one-dimensional structure will be obtained; $(b)$ correlations among 
items will be moderate, and will therefore not provide redundant information; (c) correlations among swLs scores, resilience, and humor as a copying mechanism will be positive; $(d)$ the correlation among swLs scores and depressive symptoms will be negative; (e) the magnitude of the reliability coefficients of the swLs scores will be moderate.

The study is justified by the need to have a brief sL measurement within the aging process that is of easy implementation and interpretation and has adequate validity and reliability evidences, for the use of health personnel, workers of social work fields and other related professional activities with EP. This is even more important if the increase in Peru of the persons older than 60 years old, who currently represent approximately $7.6 \%$ of the overall Peruvian population and which is estimated to rise up to $15.7 \%$ in 2050 is taken into account $(54,55)$. This reality leads to a range of activities aimed at developing the EP quality of life, where also the use of well-being assessment instruments is required. Additionally, the swLs can become a very useful instrument in empirical sL assessments at national and transnational levels. This way, information drawn from the implementation of swLs will help understanding Ls from the perspective of the EP, so their needs can be better met.

\section{Materials and methods}

\section{Participants}

In this study, a total of 236 EP living in the city of Trujillo, Peru, took part, of which 185 were women (78.4\%) and 51 men (21.6\%), with an average age of $72.8 \%$ (Es $=6.90$ ), where statistically significant differences and high effect size among the age average values favoring men ( $\mathrm{t}_{(234)}=6.340, p=0.001, d=1.002$ cr $\left.95 \% 0.679-1.325\right)$ were detected (56). The majority of participants ( $\mathrm{n}=82 ; 34.7 \%)$ were spouses; $25.8 \%(\mathrm{n}=61)$ life partners; $22.5 \%$ $(n=53)$ widowed; $15.7 \%(n=37)$ divorced/separated; and 1.3\% $(n=3)$ single. The largest percentage (55.1\%) said they had a good quality of life, while only $5.5 \%$ perceived their quality of life as bad.

\section{Instruments}

All participants responded to following instruments:

Diener's Satisfaction with Life Scale (swLs) (46). It is a brief self-reporting measure of five items that assesses the overall judgement people make on their own Ls. In the present study, the Spanish swls version of Atienza, Pons, Balaguer and Garcia-Merita of five Likert response options was used, with answers ranging from "completely disagree = 1" to "completely agree = 5", where the higher scores indicate a higher Ls degree (57). This version has been used in EP before $(52,53)$. The swLs presents a one-dimensional structure, while a meta-analysis 
of 60 studies that assessed swLs reliability reported an average of the Cronbach's alpha coefficient of .78, with confidence intervals of $95 \%$, ranging from .76 to .80 (58).

Single Item of Satisfaction with Life (SISL). It is a one-dimensional sL measure, designed exclusively for this study, whose contents is "How satisfied are you with your own life in general?" The sisL has five response items ranging from "very dissatisfied = 1" to "very satisfied = 5”.

Brief Resielient Coping Scale (BRCS) (59). This brief measure is designed for assessing the ability to adaptively cope with stress, it is composed of four items with Likert response options varying from "absolutely does not describe me $=1$ " to "describes me very well = 5". According to the original English version, the вRCs is one-dimensional and presents a Cronbach's alpha coefficient of .69 as a measure of internal consistency. In the present study, the Spanish BRCs version of Caycho-Rodríguez et al (60). In this study, it evidences an adequate reliability by calculating the Cronbach's alpha coefficients ( $\alpha=.874$; c $95 \%$ : $.84-.90)$ and Omega $(\omega=.878)$.

Geriatric Depression Scale - 5 items (GDs-5) (61). This is the five items version that assesses depressive symptoms in $\mathrm{EP}$ in the immediately preceding weeks by means of dichotomous responses (Yes/No). For this study, a reliability coefficient of .76 (ic 95 \%: .70 - .81) was obtained.

\section{Data Gathering Process}

All patients completed the sL, resilience and depression measures, in addition to providing information about age, gender, family coexistence and marital status. The instruments were distributed collectively in some cases, and individually in other, adhering to ethical and privacy standards, as well as complying with the informed consent and having the permission of the authorities of the Centros del Adulto Mayor-CAM- (Centers for the Elderly) of the Social Security (EsSalud) of the city of Trujillo. The study had the approval of the Committee of Ethics of the Universidad Privada del Norte.

\section{Statistical Analysis}

The initial analysis helped calculating descriptive (average, standard deviation) and distribution (asymmetry and kurtosis) measures for each of the five swls items. The Mardia's multivariate normality coefficient was calculated, thus contributing to the decision of the most appropriate estimation method (62).

A confirmatory factorial analysis (CFA) was conducted to explore the internal swLS structure using the polychoric correlation matrix and the maximum likelihood estimation method $(63,64)$. The use of $C F A$ is justified by the existence of previous information on the swls factorial structure used in preceding researches $(48-50,53)$. The goodness of fit model was assessed following recommendations of Hancock and Mueller: chi square 
$(\chi 2)$, goodness of fit index ( $(G F I$ ), comparative fit index (CFI), normalized fit index (NFI), root mean squared error of approximation (RMSEA), and standard root mean squared residual (SRMR) (65). Although the $\chi 2$ is the most widely used method for assessing the goodness of fit, it has the limitation of being very sensitive to the sample size (66). Against this background, the relative squared chi calculation for the model $(\chi 2 / d f)$ was included, where values between 2 and 3 or up to a difference $\leq 5$ indicate a good fit model $(64,67,68)$. On the whole, GFI, CFI and NFI $>.95$ values, as well as RMSEA and SRMR $<.08$ values indicate an adequate fit between the hypothetical model and the data (69). It was considered that the standardized factorial loads $(\lambda)$ are adequate when starting from a value of $\lambda \geq .50$ (69). Additionally, in order to obtain internal evidence of convergent validity, the average variance extracted (AVE) from the factor was calculated, where values $>.50$ are considered satisfactory (70). Internal evidences of discriminant validity are assessed by means of the item-total correlations.

The reliability of the swLs scores was assessed using the Cronbach's alpha coefficient complemented with confidence intervals by $95 \%$ (сг) calculated by the MS Excel ${ }^{\circledR}$ ICalfa module, the omega coefficient $(\omega)$ with the corresponding cI and the greatest lower bound (GLB) (71-74). The alpha coefficients were compared based on the ci of the difference between two parameters (75).

The swls convergent and discriminant validity evidence was estimated through de Pearson's correlation coefficient between the swls score and other measures that are theoretically related with the LS (SISL, BRCS and GDS-5), calculating the correlations' effect size (ES) ( $r ; \geq .20$ : recommended minimum; $\geq .50$ : moderate; $\geq .80$ : strong) and the corresponding ci by the MS Excel@ module designed for this case (76).

Ultimately, the descriptive and correlational statistical analyses were conducted with SPSS. 22, while EQS 6.2 was used for the AFC.

\section{Results}

\section{Descriptive Analysis of the swLs Items}

Table 1 shows the statistical descriptions of the five swls items. The item number 5 ("In most respects, my life is as I want it to be") has the largest average value $(M=3.69)$, and the item number 4 ("If I could live my life over, I would repeat it just the same way it has been") has the lowest $(M=3.55)$. All items present adequate asymmetry and kurtosis $( \pm 1.5)$. Likewise, the Mardia's coefficient value of 13.49 lies within the limits considered adequate $(<70)$, thus allowing the assumption of multivariate normality and not affecting the estimations based on the maximum likelihood method $(77,78)$. 
Table 1. Mean values, standard deviations, asymmetry, kurtosis and correlation among the Diener's Satisfaction with Life Scale (swLs) items

\begin{tabular}{|c|c|c|c|c|c|c|c|c|}
\hline \multirow[t]{2}{*}{ Item } & \multirow[t]{2}{*}{ M } & \multirow[t]{2}{*}{ D.E. } & \multirow[t]{2}{*}{ g1 } & \multirow[t]{2}{*}{ g2 } & & & & \\
\hline & & & & & Item 1 & Item 2 & Item 3 & Item 4 \\
\hline $1^{*}$ & 3.58 & 1.12 & -.54 & -.31 & & & & \\
\hline $2^{* *}$ & 3.58 & 1.01 & -.87 & .47 & .760 & & & \\
\hline $3^{* * *}$ & 3.58 & 1.03 & -.72 & .08 & .756 & .791 & & \\
\hline $4^{* * * *}$ & 3.55 & .74 & -.90 & .97 & .592 & .619 & .616 & \\
\hline $5^{* * * * *}$ & 3.69 & .98 & -.65 & -.08 & .775 & .810 & .806 & .631 \\
\hline
\end{tabular}

Note: $\mathrm{M}$ = Mean; $\mathrm{DE}$ = Standard Deviation; g1 = Asymmetry; g2 = Kurtosis.

Item $1^{*}=$ "In most respects, my life is as I want it to be"; Item $2^{* *}=$ "So far I have gotten the important things I want in life"; Item $3^{* * *}=$ "I am satisfied with my life"; Item $4^{* * * *}=$ "If I could live my life over, I would repeat it just the same way it has been"; Item $5^{* * * * *}=$ "The conditions of my life are good".

\section{Evidence of the swLs Internal Structure}

The AFC was used for establishing the goodness of fit of the swLs one-dimensional model previously identified in the specialized literature. Results show that the one-dimensional model presents a good data fit $(\chi 2=10.960, d f=5, p=.05, \chi 2 / d f=2.192$, GFI $=.983, C F I=.994$, NFI $=.988 ;$ RMSEA $=.071$ [сі $90 \% .000, .129$ ]; and SRMR $=.013$ ). Standardized factorial loads $(\lambda)$ for the one-dimensional model (Item $1=.85$; Item $2=.89$; Item $3=.89$; Item $4=.69$; Item $5=.91$ ) are all statistically significant $(p<.05)$, with the expected direction and with a $\lambda_{\text {Mean }}$ of .847 above the recommended $(\lambda>$.70) (64). The one-dimensional model presents also internal evidences of discriminant validity evidence since they do not show correlations above .90 among the swLS items (table 1), thus indicating a lack of multicollinearity (79). The AVE $=.723$ value provides internal evidence of convergent validity for it is superior to .50 (70).

Table 2 presents the comparison of the goodness of fit indexes reported in this study that was also pointed out in previous researches. Fit indexes similar to the reported in the international literature are evidenced, although in some cases all the required values needed for establishing a comparison are not available. 
Tabla 2. Goodness of fit indexes, reliability coefficients, swls factorial loads reported in this and other studies on elderly people

\begin{tabular}{|c|c|c|c|c|c|c|c|c|c|c|c|}
\hline \multirow[b]{2}{*}{ Autor } & \multirow{2}{*}{ 胥 } & \multicolumn{4}{|c|}{ Goodness of Fit Indexes } & \multirow[b]{2}{*}{$\begin{array}{l}\text { Cronbach's Alpha } \\
\text { Coefficients }\end{array}$} & \multicolumn{5}{|c|}{ Factorial Loads } \\
\hline & & CFI & GFI & RMSE & SRMR & & $\begin{array}{c}\text { Item } \\
1 \\
\end{array}$ & $\begin{array}{c}\text { Item } \\
2 \\
\end{array}$ & $\begin{array}{c}\text { Item } \\
3 \\
\end{array}$ & $\begin{array}{c}\text { Item } \\
4 \\
\end{array}$ & $\begin{array}{c}\text { Item } \\
5 \\
\end{array}$ \\
\hline $\begin{array}{c}\text { Caycho-Rodríguez } \\
\text { et al. }^{\mathrm{a}}\end{array}$ & 己્d & .99 & .98 & .071 & .01 & $\begin{array}{c}\alpha=.93 \\
\text { [IC } 95 \%: .90-.94]\end{array}$ & .85 & .89 & .89 & .69 & .91 \\
\hline $\begin{array}{l}\text { Durak } \\
\text { et al., } 2010\end{array}$ & 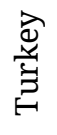 & .99 & $-\mathrm{b}$ & .22 & .02 & $-\mathrm{b}$ & $-\mathrm{b}$ & $-\mathrm{b}$ & $-\mathrm{b}$ & $-\mathrm{b}$ & $-b$ \\
\hline $\begin{array}{l}\text { López-Ortega } \\
\text { et al., } 2016^{\mathrm{e}}\end{array}$ & 얼 & $-\mathrm{b}$ & $-\mathrm{b}$ & $-\mathrm{b}$ & $-\mathrm{b}$ & $\begin{array}{c}a=.74 \\
{[\text { CI } 95 \%: .73-.75]^{d}}\end{array}$ & .67 & .76 & .83 & .78 & .61 \\
\hline $\begin{array}{l}\text { Pons } \\
\text { et al., 2002a }\end{array}$ & 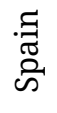 & -b & .97 & $-\mathrm{b}$ & $-\mathrm{b}$ & $\begin{array}{c}a=.71 \\
{[\text { CI } 95 \%: .61-.78]^{d}}\end{array}$ & .65 & .51 & .83 & .40 & .91 \\
\hline $\begin{array}{l}\text { Requena } \\
\text { et al., } 2009^{\text {a,e }}\end{array}$ & 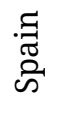 & .99 & .98 & .031 & $-\mathrm{b}$ & $\begin{array}{c}\alpha=.75 \\
{[\text { сI } 95 \%: .70-.79]^{d}}\end{array}$ & .67 & .63 & .77 & .69 & .81 \\
\hline $\begin{array}{l}\text { Sancho } \\
\text { et al., } 2014\end{array}$ & $\begin{array}{l}\frac{\pi}{1} \\
\infty \\
\sum^{2}\end{array}$ & .97 & .91 & .13 & .03 & $\begin{array}{c}\alpha=.92 \\
{[\text { CI } 95 \%: .91-.93]^{\mathrm{d}}}\end{array}$ & .84 & .88 & .94 & .88 & .69 \\
\hline $\begin{array}{l}\text { Schnettler } \\
\text { et al., } 2017^{c}\end{array}$ & 坣 & .99 & $-b$ & .069 & $-\mathrm{b}$ & $\begin{array}{c}a=.84 \\
{[\text { cI } 95 \%: .82-.86]^{\mathrm{d}}}\end{array}$ & $-\mathrm{b}$ & $-\mathrm{b}$ & $-\mathrm{b}$ & $-\mathrm{b}$ & $-\mathrm{b}$ \\
\hline $\begin{array}{l}\text { Schnettler } \\
\text { et al., } 2017^{c}\end{array}$ & 䒓 & .99 & $-\mathrm{b}$ & .035 & $-\mathrm{b}$ & $\begin{array}{c}\alpha=.79 \\
{\left[\text { CI 95\%:.77-.82] }{ }^{\mathrm{d}}\right.}\end{array}$ & $-b$ & $-\mathrm{b}$ & $-\mathrm{b}$ & $-b$ & $-b$ \\
\hline
\end{tabular}

a. The items are taken from the Atienza et al. (2000) version. Item 1 = "In most respects, my life is as I want it to be"; Item 2 = "So far I have gotten the important things I want in life"; Item 3 = "I am satisfied with my life"; Item 4 = "If I could live my life over, I would repeat it just the same way it has been"; Item 5 = "The conditions of my life are good".

b. Hyphens represent that values have not been included in the original article.

c. Fit indexes and reliability coefficients of the compared models in the factorial invariance between the Ecuadorian and Chilean samples were considered.

d. cI 95\% are not reported in the original articles, but have been calculated based on the data found there.

e. Reported factorial loads are drawn from AFE and not from AFC.

Note: $\mathrm{CFI}$ = Comparative Fit Index; GFI = Goodness of Fit Index; RMSEA = Root Mean Squared Error of Approximation; SRMR = Standard Root Mean Squared Residual; $\alpha$ = Cronbach's Alpha Coefficient; cI = Confidence Intervals. 


\section{Convergent and Discriminant Validity Evidence}

In order to assess the convergent and discriminant validity, the correlation among the swLS scores was calculated with a single item of satisfaction of life scale (sISL), resilience (BRCS) and depression (GDS-5). In this sense, results report that the swLs score is positively correlated with the SISL $(r=.898, p<.01$ [сі $95 \%: .87, .96$ ]) and the вRCS ( $r=.992, p<.01$ [сі $95 \%: .98, .99$ ]); while with the GDs-5 a negative correlation was established ( $r=-.584, p<.01$ [cr $95 \%$ : -.49, -.79]). All correlations show the expected direction, are statistically significant and present a moderate $(r \geq .50)$ and strong $(r \geq .80)$ ES (76).

\section{Reliability Estimate}

The reliability of the swls one-dimensional model scores were assessed. The results of the calculation of the Cronbach's alfa coefficient ( $\alpha=.93$; cr $95 \%: .90$ - .94), the omega coefficient ( $\omega=.93$; cr $95 \%: .92-.95)$, and the GLB $=.94$ provide evidence of an adequate reliability. Table 2 shows a higher alpha coefficient value compared with the findings of the previous studies. The $\omega$ coefficient value was not compared since the preceding studies did not report it.

In order to complete the reliability analysis, the difference between the $\alpha$ coefficients reported in the present study and the other international works on the basis of the data indicated in table 2 was estimated. This procedure aimed at evaluating whether there are statistically significant differences in the estimate of error in the compared samples or not (75). Results point out that only the cr $95 \%$ of the difference between the alpha values of the present study and the ones of Sancho et al. (cr 95\%: -.022 to .002) is statistically significant, thus evidencing that the swls estimates the error in a similar way in Peruvian and Angolan EP (48). On the contrary, results prove an existing difference in the estimation of error when comparing alpha values of the Peruvian EP sample with Mexican Ер (сг $95 \%$ : .16 to .20), with institutionalized Spanish ЕP (сг $95 \%: .14$ to .32), with Spanish active elderly women (сг $95 \%: .13$ to .23), with Chilean ер (сг $95 \%: .05$ to .11), and with Ecuadorian Ер (сг $95 \%: .09$ to .16).

\section{Discussion}

$\mathrm{T}$ The aim of the study was to determine and analyze the validity and reliability evidences of the swLs scores in a sample of Peruvian not institutionalized EP. In general, the results show adequate psychometric properties for swls, where all items presented high factorial loads, optimal fit indexes of the one-dimensional model, as well as adequate levels of internal consistency. 
Considering the construct validity analysis, the present study provides higher evidence of the swLs one-dimensional structure in EP, which coincides with what previous studies conducted in different cultural contexts report (48-50, 53). Similar findings have been reported in samples of adolescents, pregnant and postpartum women, unfertile women, persons performing physical activities, among others $(57,80-82)$. This is an important result since it allows replicating the swLs one-dimensional structure in spite of the different characteristics of the samples.

In relation to the factorial loads, these oscillated between .69 (Item 4: "If I could live my life over, I would repeat it just the same way it has been") and .91 (Item 5: "The conditions of my life are good"). In this sense, the item "If I could live my life over, I would repeat it just the same way it has been" not only presents the highest factorial loads and explains the lower us construct variance, but it also shows the weakest inter-item correlations, thus supporting the previous results in EP $(48,51,52)$. This is explained by the temporal orientation towards the past of this item compared with the remaining four that are oriented towards a current perspective, a fact that could indicate that sL in EP relates more to an assessment of life in the present rather than in the past (83). Desmyter and De Raedt provide evidences that support these results pointing out that those EP who present a negative perspective towards the future would be most likely to experiment negative feelings of affection, depressive symptoms, and lower levels of satisfaction with life. The opposite case, in which the items oriented towards the present would have the highest factorial load and would explain a higher sL percentage variance, would indicate that the ер perceive the future as a way of maintaining the positive circumstances of the present.

Convergent and discriminant validity analyses allow, in turn, providing the evidence that relations between the sL, measured through the swLs, and other sL, resilience and depression measures show the expected theoretical direction. This way, the relation between Ls and resilience is compatible with the findings of other studies with $\operatorname{EP}(60,84)$. Some authors point out that resilience in the old age plays an important role in developing well-being. In this sense, resilient ЕP adequately cope with many stressing situations because they put into use personal (v.g. positive emotions) and interpersonal (family support) mechanisms that help them adapt and experiment higher Ls levels (84-86).

On the other side, sL is a construct that is directly associated to depression in the EP population (36). This relation is even more important if it is borne in mind that internationally about $10 \%$ of not institutionalized EP suffer from some kind of depressive condition, a percentage that increases up to approximately $30.5 \%$ in institutionalized EP (87-88). In Peru, about $81.2 \%$ of the institutionalized EP have depression, while other authors point out that there are no significant differences considering this in institutionalized and non-institutionalized ЕP (89-90). The negative relation between depression and sL suggests that an 
adequate intervention in case of depression or the risk of suffering from it could lead to a better satisfaction with life (91).

The value resulting from the reliability analysis by internal consistency conducted through alpha coefficient calculation $(\alpha=.93)$ is considered to be optimal $(\geq .70)$ and higher than those registered by previous international studies with EP. Additionally, empiric evidence was provided that leads to consider that the swls estimations of the score reliability are the same both in Peruvian and Angolan EP. The reverse is the case when comparing the results of Peruvian, Mexican, Spanish, Chilean and Ecuadorian EP, when significant differences in the reliability estimation are established. This last result would indicate that the swLs is biased towards the real score estimation of the compared samples due to the different characteristics among the samples, a fact that can lead to bias in the interpretation of the findings of the comparative and predictive transcultural studies $(75,92)$.

As regards criticism of the use of the alpha coefficient found in the literature, it was considered appropriate to calculate as well the $\omega=.93$ and GLB $=.94$ coefficients that are more adequate for factorial analysis models and suitable for screening measures in massive assessments (93-94).

The study presents certain limitations, such as the low number of elderly participants that came from a single city, this would lead to the recommendation to carry out other swLs validation studies in bigger samples of other cultural groups in Peru. Likewise, for practical reasons, participants were non-institutionalized EP, mostly living with their families or relatives, it is therefore necessary to analyze the swLs psychometric evidences in EP who are institutionalized or in clinical settings. On the other hand, this study used a series of self-reporting measures, leading the results to be prone to bias. Ultimately, the test-retest reliability was not assessed in the present study.

The results of the present study support the conclusion of considering swLs a measure that provides valid and reliable interpretations of LS in Peruvian EP. The results are important in so far as they can be used in the clinic ambit or as part of an EP general assessment system, or, within limits, for research purposes. However, further psychometric studies in EP in different regions in Peru have to be carried out.

\section{Disclaimer}

The opinions expressed in this article are those of the authors and do not necessarily represent the official position of the institution. 


\section{Conflict of Interest}

The authors certify that they have no commercial nor financial relations that could be
interpreted as conflict of interests.

\section{References}

1. Berg AI, Hoffman L, Hassing LB, McClearn GE, Johansson B. What matters, and what matters most, for change in life satisfaction in the oldest-old? A study over 6 years among individuals 80+. Aging Ment Health. 2009;13(2):191-201. Dor: 10.1080/13607860802342227

2. Melendez CJ, Tomas MJ, Oliver A, Navarro E. Psychological and physical dimensions explaining life satisfaction among the elderly: A structural model examination. Arch Gerontol Geriatr. 2009;48(3):291-5. Dor: 10.1016/j.archger.2008.02.008

3. Lim HJ, Min DK, Thorpe L, Lee CH. Trajectories of life satisfaction and their predictors among Korean older adults. BMC Geriatr. 2017;17(1):1-14. Dor: 10.1186/s12877-017-0485-5

4. Diener E. Subjective well-being: The science of happiness and a proposal for a national index. Am Psychol. 2000;55,34-43. DoI: 10.1037/0003-066X.55.1.34

5. Kimm H, Sull JW, Gombojav B, Yi SW, Ohrr H. Life satisfaction and mortality in elderly people: the Kangwha cohort study. BMc Public Health. 2012;12:54. Dor: 10.1186/14712458-12-54

6. Lacruz ME, Emeny RT, Baumert J, Ladwig KH. Prospective association between self-reported life satisfaction and mortality: results from the monica/kora Augsburg S3 survey cohort study. Bмc Public Health. 2011;11:579. DoI. 10.1186/1471-2458-11-579

7. Collins AL, Glei DA, Goldman N. The role of life satisfaction and depressive symptoms in all-cause mortality. Psychol Aging. 2009;24(3):696-702. Dor: 10.1037/a0016777

8. Nes RB, Czajkowski NO, Roysamb E, Orstavik RE, Tambs K, Reichborn-Kjennerud T. Major depression and life satisfaction: a population-based twin study. J Affect Disord. 2013;144(1-2):51-8. Dor: 10.1016/j.jad.2012.05.060

9. Chioqueta AP, Stiles TC. The relationship between psychological buffers, hopelessness, and suicidal ideation: identification of protective factors. Crisis. 2007;28(2):67-73. Dor: 10.1027/0227-5910.28.2.67

10. Frijters P. Measuring happiness, The economics of well-being. Measuring happiness, The Economics of Well-Being. 2016;53:180-3. Dor: 10.1016/j.joep.2015.09.010

11. Kobau R, Sniezek J, Zack MM, Lucas RE, Burns A. Well being assessment: An evaluation of well being scales for public health and population estimates of well being among US adults. Appl Psychol Health Well Being. 2010;2(3):272-97. Dor: 10.1111/j. 1758-0854.2010.01035.x

12. Veenhoven R. Why social policy needs subjective indicators. Soc Indic Res. 2002;58:3345. Dor: 10.1023/A:1015723614574

13. Diener E, Suh E. Measuring quality of life: Economic, social, and subjective indicators. Soc Indic Res. 1997;40(1-2):189-216. Dor: 10.1023/A:1006859511756 
14. Diener E, Ryan K. Subjective well-being: A general overview. S Afr J Psychol. 2009;39(4):391406. DOI: $10.1177 / 008124630903900402$

15. Rodgers V, Neville S, La Grow S. Health, functional ability and life satisfaction among older people 65 years and over: a cross-sectional study. Contemp Nurse. 2017;53(3):28492. DoI: $10.1080 / 10376178.2017 .1319286$

16. Fagerström C, Lindwall M, Berg AI, Rennemark M. Factorial validity and invariance of the Life Satisfaction Index in older people across groups and time: Addressing the heterogeneity of age, functional ability, and depression. Arch Gerontol Geriatr. 2012;55(2):349-56. Dor: 10.1016/j.archger.2011.10.007

17. Diener E, Suh E. Age and subjective well-being: An international analysis. Annu Rev Gerontol Geriatr. 1998;17:304-24.

18. Gaymu J, Springer S. Living conditions and life satisfaction of older Europeans living alone: a gender and cross-country analysis. Aging Soc. 2010; 30(7):1153-75. Dor: 10.1017/ S0144686X10000231

19. Stone A, Schwartz J, Broderick J, Deaton A. A snapshot of the age distribution of psychological well-being in the United States. Proc Natl Acad Sci. 2010;107:9985-90. DoI: $10.1073 /$ pnas.1003744107

20. Baird BM, Lucas RE, Donnellan MB. Life satisfaction across the lifespan: Findings from two nationally representative panel studies. Soc Indic Res. 2010;99(2):183-203. DoI: 10.1007/s11205-010-9584-9

21. Enkvist Å, Ekström H, Elmståhl S. What factors affect life satisfaction (Ls) among the oldest-old? Arch Gerontol Geriatr. 2012;54(1):140-5. Dor: 10.1016/j.archger.2011.03.013

22. Gerstorf D, Ram N, Mayraz G, Hidajat M, Lindenberger U, Wagner GG, et al. Late-life decline in well-being across adulthood in Germany, the United Kingdom, and the United States: Something is seriously wrong at the end of life. Psychol Aging. 2010;25(2):477-85. DOI: 10.1037/0012-1649.44.4.1148

23. Gerstorf D, Ram N, Röcke C, Lindenberger U, Smith J. Decline in life satisfaction in old age: Longitudinal evidence for links to distance-to-death. Psychol Aging. 2008;23(1):154-68. Dor: 10.1037/0882-7974.23.1.154

24. Gerstorf D, Ram N, Estabrook R, Schupp J, Wagner GG, Lindenberger U. Life satisfaction shows terminal decline in old age: Longitudinal evidence from the German Socio-Economic Panel Study (soep). Dev Psychol. 2008;44(4):1148-59. Dor: 10.1037/00121649.44.4.1148

25. Kunzmann U, Little TD, Smith J. Is age-related stability of subjective well-being a paradox? Cross-sectional and longitudinal evidence from the Berlin Aging Study. Psychol Aging. 2000;15(3):511-26. DoI: 10.1037//0882-7974.15.3.51

26. Uma L, Kavitha V, Swachita P. Satisfaction with Life in Elderly with reference to gender, age and residence. J Humanit Soc Sci. 2015;20:57-9.

27. Hansen T, Slagsvold B. The age and subjective well-being paradox revisited: A multidimensional perspective. Nor Epidemiol. 2012;22(2):187-95. Dor: 10.5324/nje.v22i2.1565 
28. Whitbourne SK, Sneed JR. Paradox of well-being, identity processes, and stereotype threat: Ageism and its potential relationships to the self in later life. In: Nelson TD, editor. Ageism: Stereotyping and prejudice against older persons. Cambridge: mit Press; 2002. p. 247-73.

29. Yang F, Gu D, Mitritski A. Frailty and life satisfaction in Shanghai older adults: The roles of age and social vulnerability. Arch Gerontol Geriatr. 2016;67:68-73. Dor: 10.1016/j. archger.2016.07.001

30. Fujita F, Diener E. Life satisfaction set point: stability and change. J Pers Soc Psychol. 2005;88(1):158-64. Dor: 10.1037/0022-3514.88.1.158

31. Hamarat E, Thompson D, Steele D, Matheny K, Simons C. Age differences in coping resources and satisfaction with life among middle-aged, young-old, and oldest-old adults. J Genet Psychol. 2002;163(3):360-7. Dor: 10.1080/00221320209598689

32. Gana K, Bailly N, Saada Y, Joulain M, Trouillet R, Hervé C, et al. Relationship between life satisfaction and physical health in older adults: A longitudinal test of cross-lagged and simultaneous effects. Health Psychol. 2013;32(8):896-904. Dor: 10.1037/a0031656

33. Bowling A. Do older and younger people differ in their reported well-being? A national survey of adults in Britain. Fam Pract. 2011;28(2):145-55. Dor: 10.1093/fampra/cmq082

34. Hsu HC. Trajectories and covariates of life satisfaction among older adults in Taiwan. Arch Gerontol Geriatr. 2012;55:210-16. Dor: 10.1016/j.archger.2011.08.011

35. Carmel S, Bernstein JH. Gender differences in physical health and psychosocial well being among four age-groups of elderly people in Israel. Int J Aging Hum Dev. 2003;56(2): 113-31. DoI: 10.2190/87YH-45QN-48TY-9HN8

36. Won MR, Choi YJ. Are Koreans prepared for the rapid increase of the single-household elderly? Life satisfaction and depression of the single-household elderly in Korea. The Scientific World Journal. 2013:1-4. Dor: 10.1155/2013/972194

37. Banjare P, Dwivedi R, Pradhan J. Factors associated with the life satisfaction amongst the rural elderly in Odisha, India. Health Qual Life Outcomes. 2015;13(201):1-13. DoI: 10.1186/s12955-015-0398-y

38. Waddell EL, Jacobs-Lawson JM. Predicting positive well-being in older men and women. Int J Aging Hum Dev. 2010;70(3):181-97. Dor: 10.2190/AG.70.3.a

39. Sivertsen H, Bjørkløf GH, Engedal K, Selbæk G, Helvik AS. Depression and quality of life in older persons: a review. Dement Geriatr Cogn Disord. 2015;40(5-6):311-39. DoI: $10.1159 / 000437299$

40. Katon WJ. Epidemiology and treatment of depression in patients with chronic medical illness. Dialogues Clin Neurosci. 2011;13(1):7-23.

41. Fagerstrom C, Borg C, Balducci C, Burholt V, Wenger C, Ferring D, et al. Life satisfaction and associated factors among people aged 60 years and above in six European countries. Appl Res Qual Life. 2007;2(1):33-50. Dor: 10.1007/s11482-007-9028-0

42. Bigot A. The relevance of American life satisfaction indices for research on British subjects before and after retirement. Age Ageing. 1974;2:113-21. Dor: 10.1093/ageing/3.2.113

43. Lawton MP. The Philadelphia Center Morale Scale, a revision. J Geriatr. 1975;30:85-9. Dor: 10.1093/geronj/30.1.85 
44. Salamon MJ, Conte VA. Manual for the Salamon-Conte Life Satisfaction in the Elderly Scale (lses). Odessa: Psychological Assessment Resources; 1984.

45. Lou WV, Chi I, Mjelde-Mossey LA. Development and validation of a life satisfaction scale for Chinese elders. Int J Aging Hum Dev. 2008;67(2):149-70. Dor: 10.2190/AG.67.2.c

46. Diener E, Emmons RA, Larsen RJ, Griffin S. The Satisfaction with Life Scale. J Pers Assess. 1985;49:71-5. Dor: 10.1207/s15327752jpa4901_13

47. Gouveia VV, Milfont TL, Da Fonseca PN, de Miranda Coelho JAP. Life satisfaction in Brazil: Testing the psychometric properties of the Satisfaction with Life Scale (swLs) in five Brazilian samples. Soc Indic Res. 2009;90(2):267-77. Dor: 10.1007/s11205-008-9257-0

48. Sancho P, Galiana L, Gutierrez M, Francisco EH, Tomas JM. Validating the Portuguese version of the Satisfaction with Life Scale in an elderly sample. Soc Indic Res. 2014;115(1):45766. Dor: 10.1007/s11205-012-9994-y

49. Schnettler B, Miranda-Zapata E, Lobos G, Adasme-Berrios C, Hueche C. Measurement invariance in the Satisfaction with Life Scale in Chilean and Ecuadorian older adults. Pers Individ Dif. 2017;110:96-101. DoI: 10.1016/j.paid.2017.01.036

50. Durak M, Senol-Durak E, Gencoz T. Psychometric properties of the Satisfaction with Life Scale among Turkish university students, correctional officers, and elderly adults. Soc Indic Res. 2010;99(3):413-29. Dor: 10.1007/s11205-010-9589-4

51. López-Ortega M, Torres-Castro S, Rosas-Carrasco O. Psychometric properties of the Satisfaction with Life Scale (swls): secondary analysis of the Mexican Health and Aging Study. Health Qual Life Outcomes. 2016;14(1):170-6. Dor: 10.1186/s12955-016-0573-9

52. Pons D, Atienza FL, Balaguer I, García-Merita M. Propiedades psicométricas de la escala de satisfacción con la vida en personas de tercera edad. Revista Iberoamericana de Diagnóstico y Evaluación Psicológica. 2002;13(1):71-82.

53. Requen C, López V, González R, Ortiz T. Propiedades psicométricas de la Escala de Satisfacción con la Vida en mujeres mayores activas. Rev Esp Geriatr Gerontol. 2009;44(3):146-8. DoI: 10.1016/j.regg.2009.01.002

54. Instituto Nacional de Estadística e Informática. Situación de salud de la población adulta mayor 2015. Lima: Instituto Nacional de Estadística e Informática; 2016.

55. Instituto Nacional de Estadística e Informática. Perú: estimaciones y proyecciones de población 1950-2050. Lima: Instituto Nacional de Estadística e Informática; 2016.

56. Ferguson CJ. An effect size primer: A guide for clinicians and researchers. Prof Psychol Res Pr. 2009;40(5):532-8. DoI: 10.1037/a0015808

57. Atienza FL, Pons D, Balaguer I, García M. Propiedades psicométricas de la Escala de Satisfacción con la Vida en adolescentes. Psicothema. 2000; 12(2): 314-9.

58. Vassar M. A note on the score reliability for the Satisfaction with Life Scale: An RG study. Soc Indic Res. 2008;86(1):47-57. DoI: 10.1007/s11205-007-9113-7

59. Sinclair VG, Wallston KA. The development and psychometric evaluation of the Brief Resilient Coping Scale. Assessment. 2004; 11: 94-101. Dor: 10.1177/1073191103258144 
60. Caycho-Rodríguez T, Ventura-León J, García-Cadena CH, Tomás JM, Dominguez-Vergara J, Daniel L, et al. Evidencias Psicométricas de una Medida Breve de Resiliencia en Adultos Mayores Peruanos no Institucionalizados. Psicosoc Interv. 2018;27(2): 73-79. DoI: $10.5093 /$ pi2018a6

61. Gómez-Angulo C, Campo-Arias A. Geriatric depression scale (GDs-15 and GDS -5): A study of the internal consistency and factor structure. Universitas Psychologica. 2011; 10(3):735-43.

62. Mardia KV. Measures of multivariate skewness and kurtosis with applications. Biometrika. 1970;57(3):519-30. Dor: 10.1093/biomet/57.3.519

63. Elosua OP, Zumbo BD. Coeficientes de fiabilidad para escalas de respuesta categórica ordenada. Psicothema. 2008;20(4):896-901.

64. Hair J, Anderson R, Tatham R, Black W. Análisis multivariante. México, D.F.: Prentice Hall; 2014.

65. Hancock GR, Mueller RD. Structural equation modeling. A second course. Greenwich: IAP; 2006.

66. Fujikoshi Y. Transformations with improved chi-squared approximations. J Multivar Anal. 2000;72(2):249-63. Dor: 10.1006/jmva.1999.1854

67. Bollen KA. Structural equation models. In Armitage P, Colton T, editors. Encyclopedia of biostatistics. Sussex: Wiley; 1998. p. 4363-72.

68. Carmines EG, McIver JP. Analyzing models with unobservable variables. Bohrnstedt G, Borgatta E editors. Social measurement: Current issues. Beverly Hills: Sage; 1981. p. 65-115.

69. Hu LT, Bentler PM. Cutoff criteria for fit indexes in covariance structure analysis: Conventional criteria versus new alternatives. Struct Equ Modeling. 1999;6(1):1-55. Dor: 10.1080/10705519909540118

70. Fornell C, Larcker DF. Evaluating structural equation models with unobservable variables and measurement error. J Mark Res. 1981;18:39-50. Dor: 10.2307/3151312

71. Domínguez-Lara SA, Merino-Soto M. ¿Por qué es importante reportar los intervalos de confianza del coeficiente alfa de Cronbach? Revista Latinoamericana de Ciencias Sociales, Niñez y Juventud. 2015;13(2):1326-8.

72. Ventura-León JL, Caycho-Rodríguez T. El coeficiente omega: un método alternativo para la estimación de la fiabilidad. Revista Latinoamericana de Ciencias Sociales, Niñez y Juventud. 2017; 15(1): 625-7.

73. Ventura-León JL. Intervalos de confianza para coeficiente omega: propuesta para el cálculo. Adicciones [internet]. 2017 [cited 2017 Oct 04]. Disponible en: http://www.adicciones.es/index.php/adicciones/article/viewFile/962/899

74. Jackson EH, Agunwamba CC. Lower bounds for the reliability of the total score on a test composed of nonhomogeneous items: I. Algebraic lower bounds. Psychometrika. 1977; 42(4):567-78. DoI: 10.1007/BF02295979

75. Domínguez-Lara SA, Merino-Soto C, Navarro-Loli JS. Comparación de coeficientes alfa basada en intervalos de confianza. Educ Med. 2017. Dor: 10.1016/j.edumed.2017.03.025 
76. Caycho-Rodríguez T. Tamaño del efecto e intervalos de confianza para correlaciones: aportes a Montes Hidalgo y Tomás-Sábado. Enferm Clin. 2017;27(5):331-2. Dor: 10.1016/j. enfcli.2017.07.001

77. Rodríguez MN, Ruiz MÁ. Atenuación de la asimetría y de la curtosis de las puntuaciones observadas mediante transformaciones de variables: Incidencia sobre la estructura factorial. Psicológica. 2008;29(2):205-27.

78. Ferrando PJ, Anguiano-Carrasco C. El análisis factorial como técnica de investigación en psicología. Papeles del Psicólogo. 2010;31(1):18-33.

79. Tabachnick BG, Fidell LS, Osterlind SJ. Using multivariate statistics. $4^{\text {th }}$ ed. Boston: Allyn \& Bacon; 2001.

80. Cabañero MJ, Richart M, Cabrero J, Orts MI, Reig A, Tosal B. Fiabilidad y validez de la Escala de Satisfacción con la Vida de Diener en una muestra de mujeres embarazadas y puérperas. Psicothema. 2004;16(3):448-55.

81. Maroufizadeh S, Ghaheri A, Samani RO, Ezabadi Z. Psychometric properties of the Satisfaction with Life Scale (swLs) in Iranian infertile women. Int J Reprod Biomed. 2016;14(1):57-62.

82. Núñez JL, Martín-Albo J, Domínguez E. Propiedades psicométricas de la Escala de Satisfacción con la Vida en sujetos practicantes de actividad física. Revista de Psicología del Deporte. 2010;19(2):291-304.

83. Desmyter F, De Raedt R. The relationship between time perspective and subjective well-being of older adults. Psychol Belg. 2012;52(1):19-38.

84. Hayat SZ, Khan S, Sadia R. Resilience, wisdom, and life satisfaction in elderly living with families and in old-age homes. Pakistan Journal of Psychological Research. 2016;31(2): 475-94.

85. Friborg O, Hjemdal O, Rosenvinge JH, Martinussen M, Aslaksen PM, Flaten MA. Resilience as a moderator of pain and stress. J Psychosom Res. 2006;61(2):213-9. Dor: 10.1016/j.jpsychores.2005.12.007

86. Cohn MA, Fredrickson BL, Brown SL, Mikels JA, Conway AM. Happiness unpacked: Positive emotions increase life satisfaction by building resilience. Emotion. 2009;9(3):3618. Dor: 10.1037/a 0015952

87. Martínez-De la Iglesia J, Onís-Vilches M, Dueñas-Herrero R, Albert-Colomer C, AguadoTaberné C, Luque-Luque R. Versión española del cuestionario de Yesavage abreviado (GDS) para el despistaje de depresión en mayores de 65 años: adaptación y validación. Medifam. 2002;12(10):26-40.

88. Conde JL, Jarne A. Trastornos mentales en la vejez. In Triado C, Villar F, compiladores. Psicología de la vejez. Madrid: Alianza; 2006. p. 341-64.

89. Domínguez-Lara SA, Centeno-Leyva ShB. Prevalencia de depresión en adultos mayores institucionalizados en Lima Metropolitana. Enferm Clin. 2017;27:59-60. Dor: 10.1016/j. enfcli.2016.07.009 
90. Arias WL, Yépez L, Núñez AL, Oblitas A, Pinedo S, Masías MA, et al. Felicidad, depresión y creencia en la benevolencia humana en adultos mayores institucionalizados y no institucionalizados. Propósitos y Representaciones. 2014;1(2):83-103. Dor: 10.20511/ pyr2013.v1n2.32

91. Cappeliez P, O'Rourke N. Empirical validation of a model of reminiscence and health in later life. J Gerontol B Psychol Sci Soc Sci. 2006;61(4):P237-44. Dor: 10.1093/geronb/61.4.P237

92. Merino C, Lautenschlager GJ. Comparación estadística de la confiabilidad alfa de Cronbach: Aplicaciones en la medición educacional y psicológica. Revista de Psicología. 2003; 12(2):127-36.

93. Huysamen GK. Coefficient alpha: unnecessarily ambiguous; unduly ubiquitous. South Afr J Ind Psychol. 2006;32(4):34-40.

94. Domínguez-Lara SA, Merino-Soto C. Versión breve de la Escala de Afrontamiento ante la Ansiedad e Incertidumbre Preexamen (COPEAU) en universitarios peruanos. Educ Med. 2017; Dor: 10.1016/j.edumed.2017.04.011 